\section{BRAZIULIAN JOURNAL \\ OF MEDICAL AND BIOLOGICAL RLSF.ARCH}

www.bjournal.com.br
ISSN 0100-879X

Volume 43 (04) 325-408

April 2010

BIOMEDICAL SCIENCES

AND

CLINICAL INVESTIGATION

Braz J Med Biol Res, March 2010, Volume 43(4) 330-337

Tumor necrosis factor alpha increases epithelial barrier permeability by disrupting tight junctions in Caco-2 cells

W. Cui, L.X. Li, C.M. Sun, Y. Wen, Y. Zhou, Y.L. Dong and P. Liu

The Brazilian Journal of Medical and Biological Research is partially financed by
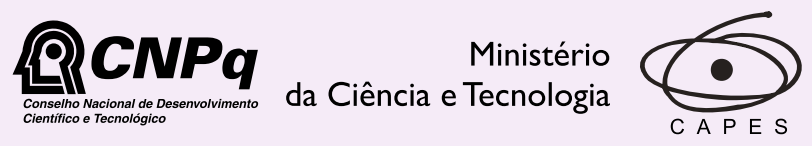

Ministério da Educação

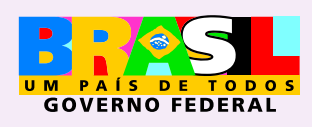

DFAPESP

Institutional Sponsors 


\title{
Tumor necrosis factor alpha increases epithelial barrier permeability by disrupting tight junctions in Caco-2 cells
}

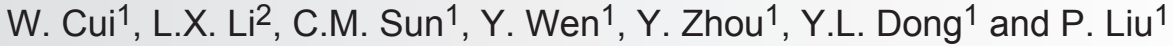 \\ ${ }^{1}$ Department of Infectious Diseases, the First Affiliated Hospital, China Medical University, \\ Shenyang, Liaoning, China \\ ${ }^{2}$ Department of Infectious Diseases, The First Hospital of Xiamen Affiliated to the Fujian Medical University, \\ Xiamen, Fujian, China
}

\begin{abstract}
The objectives of this study were to determine the effect of tumor necrosis factor alpha (TNF- $\alpha$ ) on intestinal epithelial cell permeability and the expression of tight junction proteins. Caco-2 cells were plated onto Transwell ${ }^{\circledR}$ microporous filters and treated with TNF- $\alpha(10$ or $100 \mathrm{ng} / \mathrm{mL}$ ) for $0,4,8,16$, or $24 \mathrm{~h}$. The transepithelial electrical resistance and the mucosal-to-serosal flux rates of the established paracellular marker Lucifer yellow were measured in filter-grown monolayers of Caco-2 intestinal cells. The localization and expression of the tight junction protein occludin were detected by immunofluorescence and Western blot analysis, respectively. SYBR-Green-based real-time PCR was used to measure the expression of occludin mRNA. TNF- $\alpha$ treatment produced concentration- and time-dependent decreases in Caco-2 transepithelial resistance and increases in transepithelial permeability to the paracellular marker Lucifer yellow. Western blot results indicated that TNF- $\alpha$ decreased the expression of phosphorylated occludin in detergent-insoluble fractions but did not affect the expression of non-phosphorylated occludin protein. Real-time RT-PCR data showed that TNF- $\alpha$ did not affect the expression of occludin mRNA. Taken together, our data demonstrate that TNF- $\alpha$ increases Caco-2 monolayer permeability, decreases occludin protein expression and disturbs intercellular junctions.
\end{abstract}

Key words: TNF-a; Intestinal epithelial barrier; Occludin; Caco-2 cells; Transepithelial permeability

\section{Introduction}

The intestinal mucosal barrier plays an important role in the body's protection against luminal pathogens and antigenic molecules. The intestinal barrier includes secreted mucus and the epithelial cell itself, which serves as a selective barrier permitting the uptake of nutrients, ions and other desired solutes, thus helping to maintain homeostasis of the internal environment. Pathological events such as intestinal inflammation, sepsis, burn, end-stage liver diseases, and severe pancreatitis cause impairment of the intestinal epithelial barrier. Therefore, bacteria and their lysis products, such as lipopolysaccharide, gain access to the portal and systemic circulations inducing systemic inflammatory response syndrome or even multiple organ dysfunction syndrome.

Increased intestinal epithelial barrier permeability is caused not only by exogenous factors such as infection and ischemia but also by the local immune system. Tumor necrosis factor alpha (TNF- $\alpha$ ), which is increased in many disease states, is a proinflammatory cytokine. Both in vivo and in vitro studies (1-5) have demonstrated that TNF- $\alpha$ can increase the permeability of the intestinal epithelium and that anti-TNF- $\alpha$ antibody can restore the barrier's function $(6,7)$. The precise mechanism by which TNF- $\alpha$ increases intestinal permeability is unclear. However, epithelial cell apoptosis $(3,4,8)$, protein kinase $C$, nuclear factor-kappaB, myosin light chain kinase, and mitogen-activated protein kinase are thought to be involved (9-12).

In intestinal epithelial cells, tight junctions (TJ) are the most luminal cell-to-cell junctions. They seal the paracellular space between individual epithelial cells against passive solute flux. The transmembrane proteins, occludins, claudins and zonular occludens proteins, form the TJ. Occludin, which was the first identified transmembrane

Correspondence: P. Liu, Department of Infectious Diseases, the First Affiliated Hospital, China Medical University, Shenyang, Liaoning, China. Fax: +86-24-3153-5053. E-mail: syliupei2003@yahoo.com.cn

Received June 17, 2009. Accepted March 3, 2010. Available online March 19, 2010. Published April 12, 2010. 
protein of the $\mathrm{TJ}$, is considered to be the major regulatory protein of TJs (13-15). Post-translational modifications of the occludin protein involve phosphorylation events, and multiple phosphorylation sites have been identified on occludin serine and threonine residues (16). Several proteins such as Rho kinase, protein kinase $C$, protein phosphatase $2 \mathrm{~A}$, and casein kinase 2 may regulate occludin phosphorylation $(17,18)$. The phosphorylation state of occludin mediates its association with the cell membrane and barrier permeability. Sakakibara et al. (19) demonstrated that TJ assembly induced by a calcium switch is paralleled by occludin phosphorylation, and highly phosphorylated occludin molecules are selectively concentrated at TJs, while non- or less phosphorylated occludin is localized in the cytoplasm. It has also been shown that the phosphorylation of occludin might regulate $\mathrm{TJ}$ permeability in response to histamine and lysophosphatidic acid (16).

The findings cited above lead to the conclusion that TNF- $\alpha$ can cause elevation of intestinal epithelial permeability, and the phosphorylation state of occludin may regulate TJ permeability. However, it is unclear whether the elevation of intestinal epithelial permeability induced by TNF- $\alpha$ correlates with changes in occludin phosphorylation. Therefore, in the present study, we employed Caco- 2 cells as an in vitro intestinal epithelial model, observing changes in barrier permeability, in TJs and in the expression of the highly or non-phosphorylated occludin induced by TNF- $\alpha$ to characterize the mechanism of the disruption of the epithelial barrier in response to TNF- $\alpha$.

\section{Material and Methods}

\section{Cell culture}

The Caco-2 cell line (passage 23) was obtained from the American Type Culture Collection (Manassas, USA), and stock cultures were grown in culture medium consisting of DMEM (Gibco, USA) with $4.5 \mathrm{mg} / \mathrm{mL}$ glucose, $10 \mathrm{~g} / \mathrm{L}$ non-essential amino acids (Gibco), $50 \mathrm{U} / \mathrm{mL}$ penicillin, $50 \mathrm{U} / \mathrm{mL}$ streptomycin, $4 \mathrm{mM}$ glutamine, and $20 \%$ FBS (20). The culture medium was changed every 1 to 2 days. The cells were subcultured by digestion with $0.25 \%$ trypsin and $0.9 \mathrm{mM}$ ethylenediamine-tetraacetic acid in $\mathrm{Ca}^{2+}$-free and $\mathrm{Mg}^{2+}$-free PBS. For growth on filters, Caco-2 cells were plated onto Transwell microporous filters (Corning-Costar, USA) and monitored regularly by measuring transepithelial electrical resistance (TER). For experimental purposes, only Caco- 2 cells between passages 24 and 30 were used. Cells were cultured for about 21 days before treatment. Next, cells were fed serum-free culture medium, and the medium was supplemented with the indicated concentration of TNF- $\alpha$ (10 or $100 \mathrm{ng} / \mathrm{mL}$; R\&D Systems, USA) for various times $(0,4,8,16$, or $24 \mathrm{~h})$.

\author{
Determination of Caco-2 intestinal monolayer \\ resistance and paracellular permeability \\ The TER of the filter-grown Caco-2 intestinal monolayers
}

was measured with an epithelial voltameter (World Precision Instruments, USA) as previously described (21). For resistance measurements, both the apical and basolateral sides of the epithelia were bathed in cell culture medium. Electrical resistance was measured until similar values were recorded for three consecutive measurements.

The effect of TNF- $\alpha$ on Caco-2 monolayer paracellular permeability was determined by using the paracellular marker Lucifer yellow (Sigma-Aldrich, USA) as previously described (22). DMEM, pH 7.4, was used as the incubation solution during the experiments. HBSS, pH 7.4, buffer solution $(100 \mu \mathrm{L})$ was added to the apical compartment, while $600 \mu \mathrm{L}$ was added to the basolateral compartment to ensure equal hydrostatic pressure, as recommended by the manufacturer. Known concentrations of Lucifer yellow, the permeability marker $(40 \mu \mathrm{g} / \mathrm{L})$, were added to the apical solution. Basolateral samples were taken at $60 \mathrm{~min}$, and fluorescence intensity was determined with a fluorescent plate reader. The amount of Lucifer yellow transported into the basolateral compartment was extrapolated from a standard curve. The apical-to-basolateral transport of Lucifer yellow was reported as the percentage of basolateral Lucifer yellow concentration compared with the original Lucifer yellow concentration. Low concentrations of permeability markers were used to ensure that a negligible osmotic or concentration gradient was introduced. All flux studies were carried out at $37^{\circ} \mathrm{C}$. All experiments were repeated three to six times in triplicate to ensure reproducibility.

\section{Transmission electron microscopy}

After dehydration through a graded series of ethanol, the membrane-intact Transwell insert was embedded in Araldite epoxy resin. Areas selected for ultrastructural observations and ultrathin sections ( $80 \mathrm{~nm}$ in thickness) were cut using a diamond knife and stained with saturated uranyl acetate and Reynold's lead citrate. Sections were viewed on a Hitachi $\mathrm{H} 7000$ transmission electron microscope, and images were captured digitally. Ultrastructure observations were made from multiple sites $(>10)$ of junctional complexes that were clearly identified. Three examiners analyzed at least three images from each treatment group in a blind fashion.

\section{Preparation of detergent-soluble and -insoluble protein fractions}

As previously described (19), Caco-2 cells were washed three times with ice-cold PBS, immediately incubated in Nonidet P-40 extraction buffer (25 mM HEPES, pH 7.4, $150 \mathrm{mM} \mathrm{NaCl}, 4 \mathrm{mM}$ EDTA, 1\% Nonidet P-40, $25 \mathrm{mM}$ $\mathrm{NaF}, 1 \mathrm{mM} \mathrm{Na}_{3} \mathrm{VO}_{4}, 10 \mathrm{mM}$ sodium pyrophosphate, and protease inhibitors) on ice for $30 \mathrm{~min}$ and centrifuged at $20,000 \mathrm{~g}$ for $30 \mathrm{~min}$ at $4^{\circ} \mathrm{C}$. The detergent-soluble fraction was transferred to a microcentrifuge tube and the insoluble fraction was collected in SDS extraction buffer (25 mM HEPES, pH 7.4, 4 mM EDTA, 1\% SDS, 25 mM $\mathrm{NaF}, 1 \mathrm{mM} \mathrm{Na}_{3} \mathrm{VO}_{4}$, and $10 \mathrm{mM}$ sodium pyrophosphate) 
and sonicated. Supernatants (cytoskeleton-associated fractions) were then obtained after centrifugation at 20,000 $g$ for $30 \mathrm{~min}$. Protein concentrations were measured using a Bradford Protein Assay Kit (Santa Cruz Biotechnology, USA) according to manufacturer instructions using bovine serum albumin as standard.

\section{Assessment of occludin protein expression by Western blot analysis}

Equal amounts of proteins $(50 \mu \mathrm{g})$ from each sample were separated by SDS-PAGE ( $8 \%$ polyacrylamide gel) and transferred to Immobilon ${ }^{\mathrm{TM}}$ transfer polyvinylidene difluoride membranes (Millipore, USA). Blots were blocked with $5 \%$ nonfat milk and incubated sequentially with a rabbit polyclonal occludin antibody (1:1000; Cat. \#711500, Zymed, USA) and a horseradish peroxidase-conjugated secondary antibody (1:2000) (Santa Cruz Biotechnology). Antibody binding was detected with ECL plus (Amersham Pharmacia Biotech, USA).

\section{RNA isolation and reverse transcription}

The TRIZOL ${ }^{\circledR}$ reagent (Invitrogen Life Technology, USA) was used to homogenize cells and to isolate total RNA according to manufacturer instructions. The RNA was purified by treatment with DNase I and deproteinated by $\mathrm{PI}-\mathrm{PCl}-\mathrm{ECHO}$. The concentration of total RNA was determined by absorbance at $260 / 280 \mathrm{~nm}$. Reverse transcription was carried out using the SYBR ${ }^{\circledR}$ RT-PCR kit (Takara Bio, Japan). From each sample, 500 ng total RNA was reverse-transcribed into cDNA in a $10-\mu \mathrm{L}$ reaction containing $5 \mathrm{X}$ M-MLV buffer, $250 \mu \mathrm{M}$ of each dNTP, 100 $\mu \mathrm{M}$ random hexamer, 10 units of RNase inhibitor, and 50 units of M-MLV RTase. Reactions were performed at $25^{\circ} \mathrm{C}$ for $10 \mathrm{~min}, 42^{\circ} \mathrm{C}$ for $10 \mathrm{~min}$, and $95^{\circ} \mathrm{C}$ for $2 \mathrm{~min}$.

\section{Quantification of occludin mRNA expression using real-time PCR}

SYBR-Green-based real-time PCR was used to measure relative gene expression in each sample. First, we constructed the RNA standards for the gene of interest (occludin) and for the housekeeping gene (GAPDH). To start this process, PCR primers were created. The T7 promoter was then added to a 5'-upstream primer, while twenty T's were added to a 3'-downstream primer. For the Caco-2 sample, the total RNA was reverse-transcribed and amplified by PCR (Takara Bio). For the RNA standards, the PCR products were transcribed in vitro. The RNA was treated with DNase I (Takara Bio) and purified by PI-PCI-ECHO. Samples were annealed using a gradient and amplified by real-time PCR. Then, standard curves were constructed for the gene of interest (occludin) and for the housekeeping gene (GAPDH).

The reactions for real-time PCR were carried out using the Line-gene 3310 real-time PCR detection system and the TaKaRa SYBR ${ }^{\circledR}$ RT-PCR kit (Takara). Each real-time
PCR assay contained $2 \mu \mathrm{L}$ cDNA template, $12.5 \mu \mathrm{L}$ SYBR Premix Ex Taq, and $0.25 \mu \mathrm{L}$ of each forward and reverse primer $(10 \mu \mathrm{M})$ in a $25-\mu \mathrm{L}$ reaction. Primer design for the real-time PCR was performed using Primer Express version 2 from Takara Bio. The primers used in this study were as follows: Ocln-F: 5'-AAGAGTTGACAGTCCCATGGCATA C-3', Ocln-R: 5'-ATCCACAGGCGAAGTTAATGGAAG-3'; GAPDH-F:5'-AAATGGTGAAGGTCGGTGTG-3', GAPDH-R: 5'-TGAAGGGGTCGTTGATGG-3'). All runs were performed according to the PCR protocol $\left(95^{\circ} \mathrm{C}\right.$ for $30 \mathrm{~min}$, and 45 cycles of $95^{\circ} \mathrm{C}$ for $5 \mathrm{~s}$ and $60^{\circ} \mathrm{C}$ for $20 \mathrm{~s}$. For each sample, real-time $\mathrm{PCR}$ was performed in triplicate, and the average threshold cycle $\left(C_{t}\right)$ was calculated. A standard curve was generated to convert the $C_{t}$ into copy number. Expression of occludin mRNA was normalized to GAPDH mRNA expression. The average copy number of occludin mRNA was set to 1.0 in the control samples. The relative expression of occludin mRNA in the treated samples was determined as a fold increase compared with control samples.

\section{Statistical analysis}

Data are reported as means \pm SD. Statistical analysis was performed by the Student $t$-test for unpaired data and by one-way ANOVA with the LSD post hoc test for comparison with the control. A P value of $\leq 0.05$ was used to indicate statistical significance. All experiments were repeated a minimum of three times to ensure reproducibility.

\section{Results}

\section{Effect of TNF- $\alpha$ on Caco-2 intestinal epithelial TJ permeability}

In the following studies, the effect of TNF- $\alpha$ on Caco-2 TJ permeability was determined by measuring TER and epithelial permeability to the paracellular marker Lucifer yellow. Increasing concentrations of TNF- $\alpha(0-100 \mathrm{ng} / \mathrm{mL})$ caused a dose-dependent decrease in Caco-2 TER after a 24-h period of treatment (Figure $1 \mathrm{~A}$ ). The cell monolayer TER decreased from $124.5 \pm 0.3$ to $36 \pm 0.5 \Omega / \mathrm{cm}^{2}$ after 10 $\mathrm{ng} / \mathrm{mL}$ TNF- $\alpha$ treatment, and the maximal drop in Caco-2 TER occurred when the concentration of TNF- $\alpha$ was 100 $\mathrm{ng} / \mathrm{mL}\left(28 \pm 0.7 \Omega / \mathrm{cm}^{2}\right)$. The time course of the TNF- $\alpha(100$ $\mathrm{ng} / \mathrm{mL}$ ) effect on Caco-2 TER is shown in Figure 1B. TNF- $\alpha$ did not have a significant effect on Caco-2 TER during the first $4 \mathrm{~h}$ of treatment $\left(115.5 \pm 0.6\right.$ vs $\left.128.4 \pm 1.0 \Omega / \mathrm{cm}^{2}\right)$. There was a sharp time-dependent drop in Caco-2 TER between 8 and 24 h $(8 \mathrm{~h}: 65.1 \pm 0.8,16$ h: $45.9 \pm 0.4,24$ $\mathrm{h}: 23.05 \pm 1.7 \Omega / \mathrm{cm}^{2}$ ) and the maximal drop in TER was reached by $24 \mathrm{~h}$ of TNF- $\alpha$ treatment.

Conversely, TNF- $\alpha(100 \mathrm{ng} / \mathrm{mL})$ caused a dose- and time-dependent increase in Caco-2 paracellular permeability to Lucifer yellow, and the maximal increase in paracellular permeability was also reached by $24 \mathrm{~h}$ of treatment with 100 $\mathrm{ng} / \mathrm{mL}$ TNF- $\alpha$ (Figure 2). These results indicate that TNF- $\alpha$ induced an increase in paracellular permeability. 


\section{Effects of TNF- $\alpha$ on the ultrastructure of TJ}

Since epithelial TJs regulate paracellular permeability, the ultrastructure of Caco-2 cells, treated as previously described, was analyzed by transmission electron microcopy (Figure 3). The presence of electron-dense material in the space between the cells and near the brush border reflected the TJs. In cells lacking TNF- $\alpha$ (Figure 3A), the TJ had an intact structure. In cells treated with $100 \mathrm{ng} /$ $\mathrm{mL}$ TNF- $\alpha$ in the medium for $24 \mathrm{~h}$, the TJs were reduced and contained less electron-dense material and the space between cells was enlarged (Figure 3B). These results demonstrate that TNF- $\alpha$ treatment resulted in disruption of normal TJ morphology.

\section{TNF- $\alpha$ induces a protein-specific down-regulation of occludin protein}

Western blot using an antibody specific for occludin demonstrated that both 85- and 65-kDa forms were seen in detergent-insoluble protein extracts. However, only the 65$\mathrm{kDa}$ form was seen in the detergent-soluble fraction. TNF- $\alpha$ did not affect the expression of the 65-kDa occludin in either detergent-soluble or insoluble fractions. However, it reduced the $85-\mathrm{kDa}$ occludin expression in the detergent-insoluble fractions (Figure 4). According to Sakakibara et al. (19), occludin from Madin-Darby canine kidney cells resolved as several bands between 62 and $82 \mathrm{kDa}$ by SDS-PAGE analysis. Among these bands, the lower predominant bands
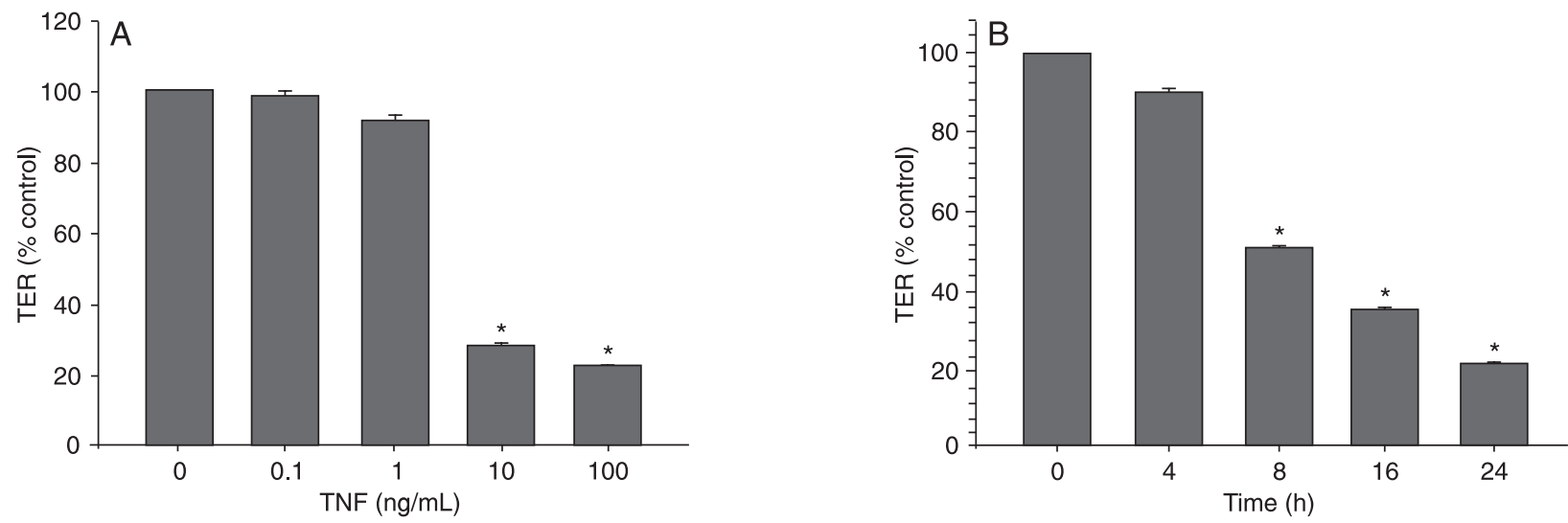

Figure 1. Effect of tumor necrosis factor alpha (TNF- $\alpha$ ) on transepithelial electrical resistance (TER). TNF- $\alpha$ produced a concentrationand time-dependent decrease in Caco-2 TER. A, Confluent Caco-2 monolayers were treated with increasing concentrations of TNF- $\alpha$ applied to the basolateral compartment and TER was measured after $24 \mathrm{~h}$. Data are reported as mean percent of control $\pm \mathrm{SD}, \mathrm{N}=$ 3 , in triplicate. ${ }^{*} \mathrm{P}<0.01$ for TER compared with control (one-way ANOVA). $B$, Confluent Caco-2 monolayers were treated with TNF- $\alpha$ $(100 \mathrm{ng} / \mathrm{mL})$ and TER was measured at the times indicated. Data are reported as the mean percent of control $\pm S D, N=3$, in triplicate. ${ }^{*} \mathrm{P}<0.01$ for TER compared with control (one-way ANOVA).
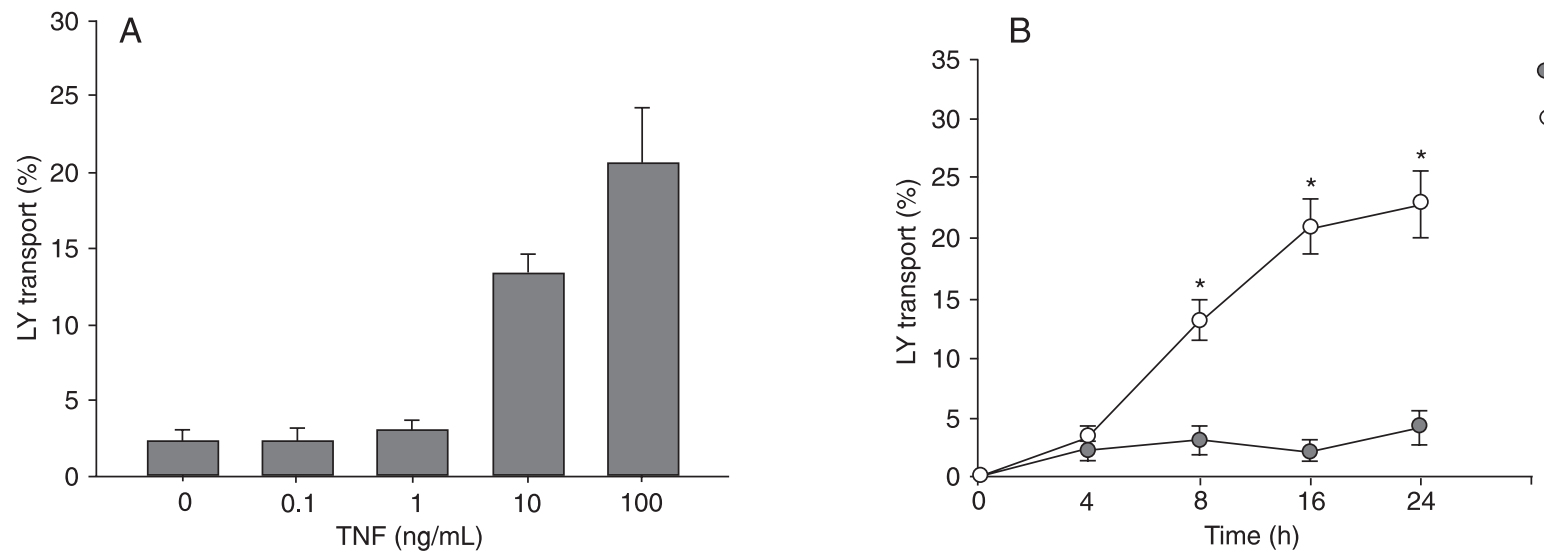

Figure 2. Effect of tumor necrosis factor alpha (TNF- $\alpha$ ) on Caco-2 paracellular permeability. The effect of TNF- $\alpha$ on Caco-2 mucosal-toserosal flux of the paracellular marker, luminal yellow (LY) was monitored as described in Material and Methods. $A$, Effect of increasing concentrations of TNF- $\alpha$ on Caco-2 transepithelial LY flux. LY flux was measured after $24 \mathrm{~h}$. B, Time-course of the effect of TNF- $\alpha$ (100 $\mathrm{ng} / \mathrm{mL}$ ) on Caco-2 transepithelial LY flux. TNF- $\alpha$ produced a concentration- and time-dependent increase in Caco-2 transepithelial LY flux. ${ }^{*} P<0.05$ for LY flux compared to control (one-way ANOVA). 

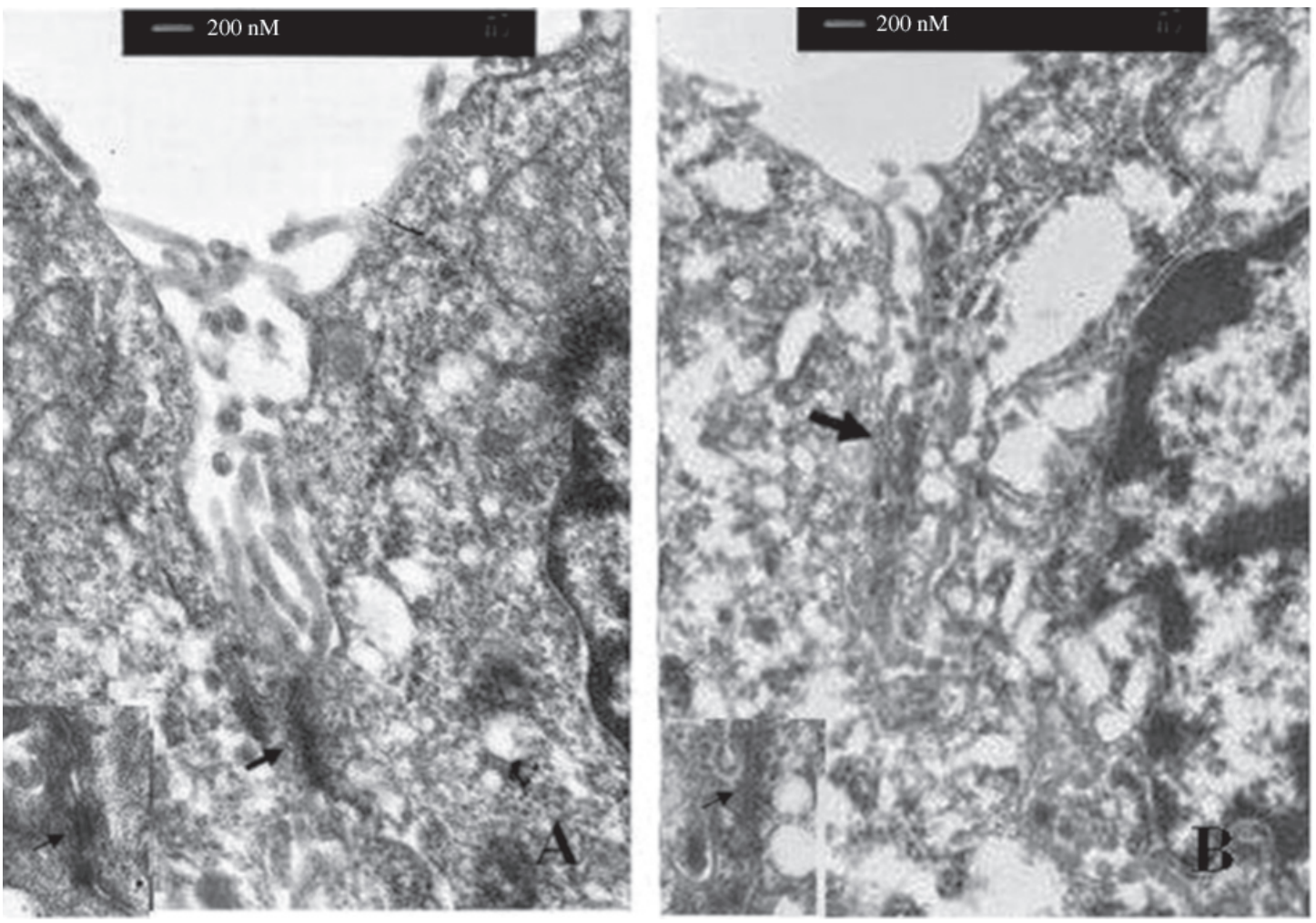

Figure 3. Effect of tumor necrosis factor alpha (TNF- $\alpha$ ) on the ultrastructure of tight junctions. Caco-2 cells were treated with (B) or without (A) $100 \mathrm{ng} / \mathrm{mL}$ TNF- $\alpha$ for $24 \mathrm{~h}$. Cells were observed by transmission electron microscopy. The junction structures between the adjoining cells are indicated by arrows. TNF- $\alpha$ produced disruption of normal TJ morphology. Bars $=200 \mathrm{nM}$.
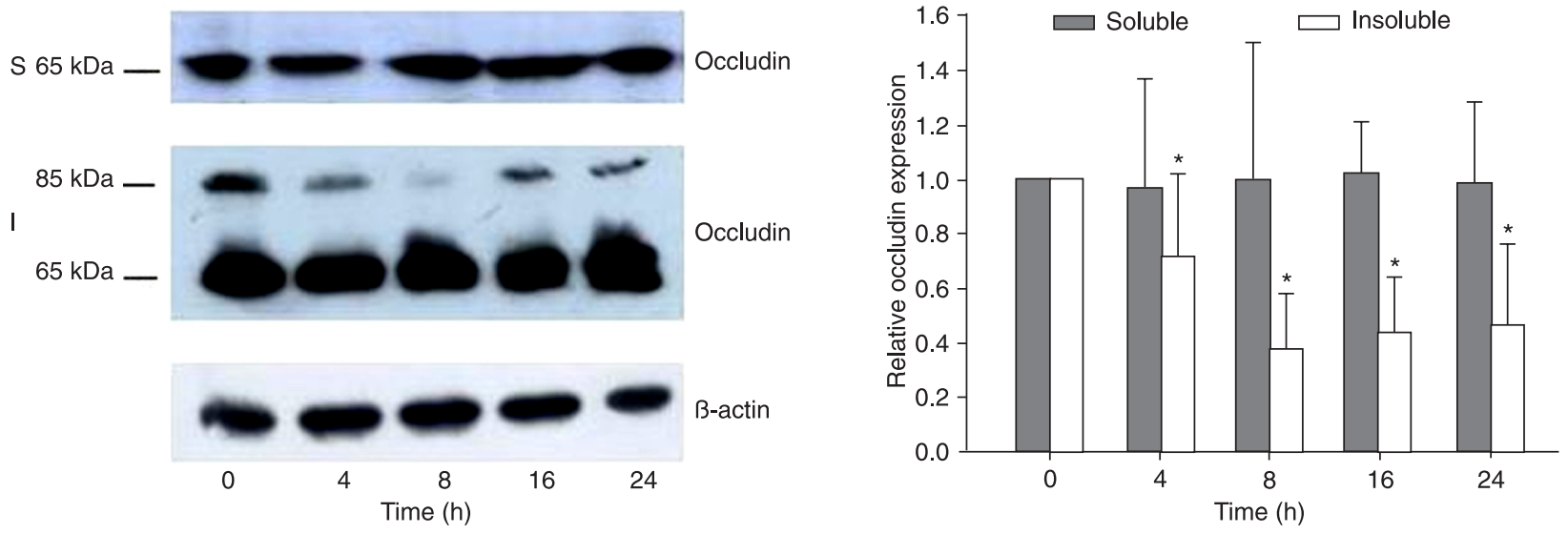

Figure 4. Time-course of the effect of tumor necrosis factor alpha (TNF- $\alpha$ ) on the expression of the tight junction protein occludin in Caco-2 monolayers. Caco-2 monolayers were treated with TNF- $\alpha(100 \mathrm{ng} / \mathrm{mL})$ for increasing times $(0-24 \mathrm{~h})$. A, Protein expression was determined by Western blot analysis with rabbit anti-occludin antibody as described in Material and Methods. The 85-kDa protein was phosphorylated and the $65-\mathrm{kDa}$ protein was less or not at all phosphorylated occludin protein. TNF- $\alpha$ did not cause any changes in detergent-soluble (S) occludin protein expression, but it did facilitate a progressive down-regulation in detergent-insoluble (I) occludin protein expression. $B$, Densitometric analysis of Western blot. Data are reported as means $\pm \mathrm{SD}$. * $<<0.05$ for occludin protein expression compared to control (one-way ANOVA). 
were essentially extracted with $1 \%$ NP-40, whereas the other higher $\mathrm{Mr}$ bands were selectively recovered in the NP-40insoluble fraction. Phosphoamino acid analyses identified phosphoserines in the higher Mr bands of occludin, and this insolubilization correlated temporally with $\mathrm{TJ}$ formation detected by immunofluorescence microscopy. Therefore, our results indicated that TNF- $\alpha$ reduced the expression of the phosphorylated and active occludin protein.

\section{Effect of TNF- $\alpha$ on occludin mRNA expression}

To examine whether the TNF- $\alpha$-induced decrease in occludin protein expression was associated with changes in occludin mRNA transcription, the effect of TNF- $\alpha$ on occludin transcript expression was determined. We set the mRNA relative expression of controls as 1 ; the results from the real-time quantitative analyses showed that there were no significant differences in occludin expression at different concentrations of TNF- $\alpha$ (10 ng/mL TNF- $\alpha$ : $0.97 \pm 0.06 ; 100$ $\mathrm{ng} / \mathrm{mL}$ TNF- $\alpha$ : $0.95 \pm 0.07 ; P>0.05)$. Similar results were shown at different times of $100 \mathrm{ng} / \mathrm{mL}$ TNF-a $(4 \mathrm{~h}: 1.02 \pm$ $0.6 ; 8$ h: $1.01 \pm 0.4 ; 16$ h: $0.98 \pm 0.3 ; 24$ h: $1.03 \pm 0.6 ; P>$ $0.05)$. These findings suggest that TNF- $\alpha$ had no effect on occludin mRNA expression.

\section{Discussion}

The intestinal barrier is primarily formed by the intestinal epithelial cells and the TJs between them. Fluxes through the intestinal epithelium mainly proceed through a transcellular route, with specific membrane pumps and channels, as well as through a paracellular route controlled by TJs. Evidence has shown that cultured epithelial monolayers lose the barrier function after exposure to TNF- $\alpha(1-4,8-$ $10,12,23-25)$. Our study also supports this viewpoint. The TER of the Caco-2 monolayers decreased in a dose- and time-dependent manner after TNF- $\alpha$ treatment. Further studies to detect paracellular permeability using Lucifer yellow, which is specifically transported through the paracellular space (26), yielded similar TER results.

There have been many hypotheses regarding the mechanism of TNF-a-induced barrier dysfunction, including epithelial apoptosis, a nonapoptotic mechanism and reduced transcription of TJ proteins $(3,4,9-12)$. However, the exact mechanism remains unclear. Claude (27) has proven that the number of TJs logarithmically correlates with the TER, indicating that TJs play an indispensable role in maintaining epithelial barrier function. To confirm whether TNF- $\alpha$ increases paracellular permeability by disrupting the structure of TJs, we observed the morphological changes of Caco-2 monolayers caused by TNF- $\alpha$ under transmission electron microscopy and found that the TJs were incontinuous after exposure to TNF- $\alpha$ (100 ng/ $\mathrm{mL}$ ) for $24 \mathrm{~h}$. Similar observations have been reported in a study of the human intestinal cell line HT-29/B6 (1). These phenomena suggest that TNF-a-induced TJ disruption was partially related to the elevation of paracellular permeability in Caco-2 monolayers.

A TJ is a macromolecular assembly of proteins that circumscribe the apical region of polarized epithelial cells. TJs are formed by different kinds of junctional proteins including transmembrane proteins such as occludin and claudins, junctional adhesion molecules, AF6, 7H6, and zonula occludens ZO-1, ZO-2, ZO-3. Occludin was the first identified transmembrane protein and is critical in maintaining the function of a TJ barrier. Studies have shown that the introduction of occludin into cultured $L$ fibroblasts formed a well-developed network of TJ strands along the cell-to-cell borders (28). The overexpression of occludin in MDCK cells increased the number of TJs and the TER of epithelial cells $(29,30)$. In addition, the transfection of Xenopus embryos with truncated occludins impaired TJ permeability (31). These observations indicate that occludin is a key component of TJs, structurally as well as functionally.

Occludins have phosphorylated and nonphosphorylated forms. The phosphorylated occludin is active and has been demonstrated to be necessary for TJ assembly $(32,33)$. Sakakibara et al. (19), using phosphoamino acid analyses, showed that phosphorylated occludin protein was selectively recovered in the NP-40-insoluble fraction and appeared in the higher Mr bands, whereas non-phosphorylated occludin protein was predominantly in the NP-40-soluble fraction and appeared in the lower Mr bands. Therefore, we prepared the NP-40-soluble and NP-40-insoluble protein fractions to hybridize with occludin antibody. Our results demonstrated that the protein within the NP-40 soluble fraction was 65 $\mathrm{kDa}$, and its expression was not affected by TNF- $\alpha$. In the NP-40-insoluble fraction, there were two molecular forms of the occludin protein, 65 and $85 \mathrm{kDa}$. Expression of the 85-kDa occludin protein was down-regulated by TNF-a, and a significant decrease occurred $4 \mathrm{~h}$ after TNF- $\alpha$ treatment, ahead of the increase in paracellular permeability induced by TNF- $\alpha$. These results indicate that TNF- $\alpha$ might change the action of the occludin protein to cause the abnormal TJ and epithelial barrier.

Regarding the effect of TNF- $\alpha$ on the expression of occludin, the results from various studies are controversial. Most studies showed that TNF- $\alpha$ had no effect on the expression of the occludin protein (34-36), whereas others found that TNF- $\alpha$ or a mixture of cytokines (TNF- $\alpha$, interferon- $y$, interleukin-1 $\beta$ ) reduced the amount and expression of occludin $(30,37,38)$. In our study, TNF- $\alpha$ changed the expression of the special phosphorylated occludin protein in Caco-2 cells, supporting the conclusion that TNF- $\alpha$ can affect the expression of TJ proteins, disrupt the TJs and increase the permeability of the intestinal barrier.

Studies have demonstrated that gene expression in the epithelial HT-29/B6 cell line mediated by promoters was down-regulated by TNF- $\alpha$ (39), which indicated that the expression of occludin was also regulated at the transcription level. Thus, we tested the effect of TNF- $\alpha$ on occludin 
mRNA by real-time PCR, and the results showed that TNF- $\alpha$, regardless of concentration and time, had no effect on the level of occludin mRNA. These findings indicate that TNF- $\alpha$ modulated occludin in Caco-2 monolayers at the protein level rather than at the transcription level.

Our results suggest that TNF- $\alpha$ increased the permeability of Caco-2 monolayers by decreasing occludin phosphorylation. The change in occludin phosphorylation

\section{References}

1. Schmitz H, Fromm M, Bentzel CJ, Scholz P, Detjen $K$, Mankertz J, et al. Tumor necrosis factor-alpha (TNF-alpha) regulates the epithelial barrier in the human intestinal cell line HT-29/B6. J Cell Sci 1999; 112 (Part 1): 137-146.

2. Gitter AH, Bendfeldt $K$, Schmitz H, Schulzke JD, Bentzel CJ, Fromm M. Epithelial barrier defects in HT-29/B6 colonic cell monolayers induced by tumor necrosis factor-alpha. Ann $N$ Y Acad Sci 2000; 915: 193-203.

3. Bojarski C, Gitter AH, Bendfeldt K, Mankertz J, Schmitz H, Wagner S, et al. Permeability of human HT-29/B6 colonic epithelium as a function of apoptosis. $J$ Physiol 2001; 535: 541-552.

4. Ma TY, Boivin MA, Ye D, Pedram A, Said HM. Mechanism of TNF-\{alpha\} modulation of Caco-2 intestinal epithelial tight junction barrier: role of myosin light-chain kinase protein expression. Am J Physiol Gastrointest Liver Physiol 2005; 288: G422-G430.

5. Ma TY, Iwamoto GK, Hoa NT, Akotia V, Pedram A, Boivin MA, et al. TNF-alpha-induced increase in intestinal epithelial tight junction permeability requires NF-kappa B activation. Am J Physiol Gastrointest Liver Physiol 2004; 286: G367-G376.

6. Suenaert P, Bulteel V, Lemmens L, Noman M, Geypens B, Van Assche G, et al. Anti-tumor necrosis factor treatment restores the gut barrier in Crohn's disease. Am J Gastroenterol 2002; 97: 2000-2004.

7. Rutgeerts P, Feagan BG, Lichtenstein GR, Mayer LF, Schreiber S, Colombel JF, et al. Comparison of scheduled and episodic treatment strategies of infliximab in Crohn's disease. Gastroenterology 2004; 126: 402-413.

8. Bruewer M, Luegering A, Kucharzik T, Parkos CA, Madara $\mathrm{JL}$, Hopkins AM, et al. Proinflammatory cytokines disrupt epithelial barrier function by apoptosis-independent mechanisms. J Immunol 2003; 171: 6164-6172.

9. Ye D, Ma I, Ma TY. Molecular mechanism of tumor necrosis factor-alpha modulation of intestinal epithelial tight junction barrier. Am J Physiol Gastrointest Liver Physiol 2006; 290: G496-G504.

10. Wang F, Graham WV, Wang Y, Witkowski ED, Schwarz BT, Turner JR. Interferon-gamma and tumor necrosis factor-alpha synergize to induce intestinal epithelial barrier dysfunction by up-regulating myosin light chain kinase expression. Am J Pathol 2005; 166: 409-419.

11. Patrick DM, Leone AK, Shellenberger JJ, Dudowicz KA, King JM. Proinflammatory cytokines tumor necrosis factor-alpha and interferon-gamma modulate epithelial barrier function in Madin-Darby canine kidney cells through mitogen activated protein kinase signaling. BMC Physiol 2006; 6: 2.

12. Clark EC, Patel SD, Chadwick PR, Warhurst G, Curry A, caused the occludin protein to detach from TJs and caused TJ disruption.

\section{Acknowledgments}

Research supported by a National Science Foundation of China (\#30670947) and the National Ministry of Health of the People's Republic of China (\#97100252).
Carlson GL. Glutamine deprivation facilitates tumour necrosis factor induced bacterial translocation in Caco-2 cells by depletion of enterocyte fuel substrate. Gut 2003; 52: 224230.

13. Furuse $M$, Hirase $T$, Itoh $M$, Nagafuchi $A$, Yonemura $S$, Tsukita S, et al. Occludin: a novel integral membrane protein localizing at tight junctions. J Cell Biol 1993; 123: 17771788.

14. Luabeya MK, Dallasta LM, Achim CL, Pauza CD, Hamilton RL. Blood-brain barrier disruption in Simian immunodeficiency virus encephalitis. Neuropathol Appl Neurobiol 2000; 26: 454-462.

15. Papadopoulos MC, Saadoun S, Davies DC, Bell BA. Emerging molecular mechanisms of brain tumour oedema. $\mathrm{Br} J$ Neurosurg 2001; 15: 101-108.

16. Hirase T, Kawashima S, Wong EY, Ueyama T, Rikitake Y, Tsukita S, et al. Regulation of tight junction permeability and occludin phosphorylation by Rhoa-p160ROCK-dependent and -independent mechanisms. J Biol Chem 2001; 276: 10423-10431.

17. Andreeva AY, Krause E, Muller EC, Blasig IE, Utepbergenov $D I$. Protein kinase $C$ regulates the phosphorylation and cellular localization of occludin. J Biol Chem 2001; 276: 3848038486.

18. Seth A, Sheth P, Elias BC, Rao R. Protein phosphatases $2 \mathrm{~A}$ and 1 interact with occludin and negatively regulate the assembly of tight junctions in the CACO-2 cell monolayer. $J$ Biol Chem 2007; 282: 11487-11498.

19. Sakakibara A, Furuse M, Saitou M, Ando-Akatsuka Y, Tsukita $\mathrm{S}$. Possible involvement of phosphorylation of occludin in tight junction formation. J Cell Biol 1997; 137: 1393-1401.

20. Ma TY, Nguyen D, Bui V, Nguyen H, Hoa N. Ethanol modulation of intestinal epithelial tight junction barrier. Am J Physiol 1999; 276: G965-G974.

21. Ma TY, Hollander D, Riga R, Bhalla D. Autoradiographic determination of permeation pathway of permeability probes across intestinal and tracheal epithelia. J Lab Clin Med 1993; 122: $590-600$.

22. Hidalgo IJ, Raub TJ, Borchardt RT. Characterization of the human colon carcinoma cell line (Caco-2) as a model system for intestinal epithelial permeability. Gastroenterology 1989; 96: 736-749.

23. Wang Q, Guo XL, Noel G, Ogle C. Heat shock stress ameliorates cytokine mixture-induced permeability by downregulating the nitric oxide and signal transducer and activator of transcription pathways in Caco-2 cells. Shock 2007; 27: 179-185.

24. Madara JL. Regulation of the movement of solutes across 
tight junctions. Annu Rev Physiol 1998; 60: 143-159.

25. Van Itallie $\mathrm{C}$, Rahner $\mathrm{C}$, Anderson JM. Regulated expression of claudin-4 decreases paracellular conductance through a selective decrease in sodium permeability. $J$ Clin Invest 2001; 107: 1319-1327.

26. Fish SM, Proujansky R, Reenstra WW. Synergistic effects of interferon gamma and tumour necrosis factor alpha on T84 cell function. Gut 1999; 45: 191-198.

27. Claude P. Morphological factors influencing transepithelial permeability: a model for the resistance of the zonula occludens. J Membr Biol 1978; 39: 219-232.

28. Furuse M, Fujita K, Hiiragi T, Fujimoto K, Tsukita S. Claudin-1 and -2: novel integral membrane proteins localizing at tight junctions with no sequence similarity to occludin. $J$ Cell Biol 1998; 141: 1539-1550.

29. McCarthy KM, Skare IB, Stankewich MC, Furuse M, Tsukita $\mathrm{S}$, Rogers RA, et al. Occludin is a functional component of the tight junction. J Cell Sci 1996; 109 (Part 9): 2287-2298.

30. Balda MS, Whitney JA, Flores C, Gonzalez S, Cereijido M, Matter K. Functional dissociation of paracellular permeability and transepithelial electrical resistance and disruption of the apical-basolateral intramembrane diffusion barrier by expression of a mutant tight junction membrane protein. $J$ Cell Biol 1996; 134: 1031-1049.

31. Chen Y, Merzdorf C, Paul DL, Goodenough DA. COOH terminus of occludin is required for tight junction barrier function in early Xenopus embryos. J Cell Biol 1997; 138: 891-899.

32. Tsukamoto T, Nigam SK. Role of tyrosine phosphorylation in the reassembly of occludin and other tight junction proteins. Am J Physiol 1999; 276: F737-F750.
33. Chen YH, Lu Q, Goodenough DA, Jeansonne B. Nonreceptor tyrosine kinase $\mathrm{c}-\mathrm{Yes}$ interacts with occludin during tight junction formation in canine kidney epithelial cells. Mol Biol Cell 2002; 13: 1227-1237.

34. Vietor I, Bader T, Paiha K, Huber LA. Perturbation of the tight junction permeability barrier by occludin loop peptides activates beta-catenin/TCF/LEF-mediated transcription. EMBO Rep 2001; 2: 306-312.

35. Poritz LS, Garver KI, Tilberg AF, Koltun WA. Tumor necrosis factor alpha disrupts tight junction assembly. J Surg Res 2004; 116: 14-18.

36. Quesnell RR, Erickson J, Schultz BD. Apical electrolyte concentration modulates barrier function and tight junction protein localization in bovine mammary epithelium. Am J Physiol Cell Physiol 2007; 292: C305-C318.

37. Han X, Fink MP, Delude RL. Proinflammatory cytokines cause NO*-dependent and -independent changes in expression and localization of tight junction proteins in intestinal epithelial cells. Shock 2003; 19: 229-237.

38. Sappington PL, Han X, Yang R, Delude RL, Fink MP. Ethyl pyruvate ameliorates intestinal epithelial barrier dysfunction in endotoxemic mice and immunostimulated caco-2 enterocytic monolayers. J Pharmacol Exp Ther 2003; 304: 464-476.

39. Mankertz J, Waller JS, Hillenbrand B, Tavalali S, Florian P, Schoneberg $\mathrm{T}$, et al. Gene expression of the tight junction protein occludin includes differential splicing and alternative promoter usage. Biochem Biophys Res Commun 2002; 298: 657-666. 